UDC 330.3(510)

DOI: https://doi.org/10.18485/iipe_ria.2021.72.1183.4

Biblid 0543-3657, 72 (2021)

Vol. LXXII, No. 1183, pp. 67-87

Review article

\title{
NEW DEVELOPMENT PARADIGM WITHIN THE CHINESE 14TH FIVE-YEAR PLAN - CHINESE VISION OF MODERN CHINA
}

\author{
Katarina ZAKIĆ ${ }^{1}$
}

\begin{abstract}
Dual Circulation" is the new Chinese development paradigm introduced in the latest $14^{\text {th }}$ Five-Year Development Plan. The author of this article explains the origin of the paradigm, how it will be implemented, as well as the main challenges that that present an obstacle to achieving the planned goals. "Dual Circulation" is the logical step in the evolution of the Chinese economy, and the planned results are ambitious. The main challenges in the implementation of the new development concept will be to expand the domestic demand, have more equal regional development, increase the domestic income, implement changes within bukou, increase the high skilled labour force, change the culture of savings, reform the state-owned enterprises, and have innovative development. The main expected changes within the world economy will be regionalization, increased selfreliance, and changes within global production and supply chains.
\end{abstract}

Keywords: New development paradigm, China, $14^{\text {th }}$ Five-Year Plan, Dual circulation, challenges, changes

\section{CHINA: CHANGES AND CHALLENGES}

Chinese five-year development plans have a long and successful tradition. Established in 1953, they have been the main source of information on the future economic development and a guideline for Chinese provincial governments, enterprises and citizens for almost seventy years. The plans reflected the time and circumstances in which they were established. The Chinese leadership had formulated some of the most known campaigns, development models, strategies, and policies through those plans. Some of the prominent ones were the Great

\footnotetext{
${ }^{1}$ Research Fellow, Head of Regional centre One Belt, One Road, Institute of International Politics and Economics. E-mail: katarina@diplomacy.bg.ac.rs

The paper presents the findings of a study developed as a part of the research project entitled 'Serbia and Challenges in International relations in 2021', financed by the Ministry of Education, Science and Technological Development of the Republic of Serbia, and conducted by the Institute of International Politics and Economics, Belgrade.
} 
Leap Forward (1958), the Open Door Policy (1978), the Going Global Policy (1999), the New Normal (2014), Made in China 2025 (2016), etc. ${ }^{2}$ They all announced changes in development phases that lead to a more developed and prosperous society.

In 2010, China became the number two economy in the world. Today, China is the number one economy in the world in regards to GDP in purchasing power parity, global exports, and percentage of global manufacturing. Almost 800 million people in China have been lifted from poverty so far, and there are constant plans to further improve the economy. All those improvements were achieved due to careful and thoughtful planning.

Until two decades ago, the plans were centred on the so-called quantitative development, while the situation changed in recent years, and qualitative development became the new focus. The aim is to achieve economic progress that will result in a better quality of life for Chinese citizens.

According to the $14^{\text {th }}$ development plan, China will endeavour to reach the goal of becoming a moderately developed country and achieve a US\$30,000 GDP per capita by the end of 2035 (Vision 2035). At the end of 2020, the GDP per capita in China was US\$10,500.396 in current US\$ (The World Bank), so the plan is to increase the GDP per capita by approximately US $\$ 19,500$ in the next 15 years.

While completing the $13^{\text {th }}$ FYP at the end of 2019, China faced the most serious challenge so far - the COVID-19 pandemic. The first three months of 2020 were especially devastating for China since some provinces were in lockdown. Navigating through the unfortunate events proved to be demanding, but China managed to recover. It carried out strong health measures that gave efficient results, and the economy was on the road to recovery. At the end of 2020, China was among the few countries that achieved positive economic results in that year.

Summarizing the results of the $13^{\text {th }} \mathrm{FYP}$, the Chinese Government stated in the newest plan that the China's GDP exceeded 100 trillion RMB, that 55.75 million people have been lifted out of poverty, more than 60 million jobs have been created in urban areas, and basic health insurance covered more than 1.3 billion people and provided basic pensions (CSET 2021). Judging by these results and despite the vast economic, political and health uncertainties, China managed to fulfil the tasks planned five years ago.

The main aim of this paper is to analyse the new development paradigm presented in the new Plan, look into its origin, see potential challenges in achieving the plans, and provide some predictions of the effects the new development

\footnotetext{
${ }^{2}$ More on the analysis of Chinese development phases and policies: Bramall Chris. 2008. Chinese Economic Development, London and New York: Routledge, Taylor and Francis Group.
} 
paradigm will have on the world economy. The main tool of the assessment was content analysis, and both scientific and empirical resources were used as relevant sources of information.

The first part of the article explains the centennial goals and their connection to the new Chinese development plan. The second part explains the concept, the origin and reasons for the introduction of "Dual Circulation" defined in the Plan. The third part describes the main challenges China will face in the fulfilment of the planned goals. Finally, the article will elaborate on what kind of changes we can expect in the world economy due to the changes in the Chinese economy.

\section{ON THE ROAD TO CHANGE - ACHIEVING CENTENNIAL GOALS}

Before the official introduction of the $14^{\text {th }} \mathrm{FYP}$, the Government made several announcements regarding the plan. The main emphasis was on two aspects. The first one was to achieve two centennial goals, and the second one was to implement a dual circulation development paradigm.

The centennial goals were incorporated into the Party's Constitution in 2012 at the $18^{\text {th }}$ National Congress of the Chinese Communist Party, and they followed Deng Xiaoping's "Three Step Development Strategy" (Lu 2016, 80). Lu pointed out, that during his famous South China Inspection Tour, Deng expressed his views on China's future, that would involve three steps (phases) in achieving them: 1) to double the size of the economy during the $80 \mathrm{~s}$; 2) to once again double the size of the economy during the 90 s, thus making China a moderately prosperous society; and 3) making China a moderately developed country by 2049 (ibidem 81). Those plans were changed later on, and renamed as two centennial goals. The first centennial goal is to build a moderately prosperous society in all respects by 2021, when the Communist Party of China will celebrate its $100^{\text {th }}$ anniversary. That meant that China would double the level of GDP per capita from the 2010 level by 2021, and reach the level of development China called a moderately prosperous society (ibidem). The second goal is "to build a modernized socialist country that is prosperous, strong, democratic, culturally advanced and harmonious until 2049", on the $100^{\text {th }}$ anniversary of establishing the PRC (Xinhua 2017).

Those plans did put pressure both on enterprises and on the Government to achieve them. The first goal will be fulfilled by the end of 2021, and that is a testament that the plans were formulated in a good way. At the same time, those goals were hard to achieve since the final year of the $13^{\text {th }}$ plan was conducted during the pandemic. The second goal is an ambitious one as well, since GDP per capita needs to almost triple in the next 15 years, and that is the so called Vision 2035. Having in mind that the pandemic is still not over, that the GDP growth 
rates of China are lower than in previous periods, and that many competitive advantages China had so far are not so competitive today, it will be a challenge to achieve it $^{3}$.

The "Dual Circulation" development model was the second main point in the announcements of the new Plan. In those first announcements, it was stated that this model would rely on "internal circulation", which will be simultaneously supported by the "external circulation". The internal circulation is focused on creating better and advanced domestic production, distribution and consumption, driven by domestic innovation. The external circulation is the continuation of the pre-existing model concentrated on the internationalization model, which was export-oriented. The official explanation before the plan was completely announced was concise, which opened the door for many speculations regarding China's ultimate intentions. Western media reports and analysts saw it as decoupling from the USA, but also as decoupling from international trade or supply chains (Pettis 2020, Blanchette \&Polk, 2020, Sheng 2021, Aglietta et all. 2021). However, Chinese colleagues ${ }^{4}$ offered their vision and understanding of the new development paradigm, insisting that this is a normal and logical phase in the Chinese development, which will enable necessary adjustments in its economy needed to achieve the second centennial goal (Hong 2018, Lin and Wang 2021, Shusong and Bai, 2020, Liu 2020, Saad et all 2021, Kwan 2021). All of them provided evidences for their conclusion, but this research aims at finding its argumentation by reviewing all of them.

\section{CHINESE VISION OF MODERN CHINA - IMPLEMENTING THE NEW DEVELOPMENT PARADIGM}

The Chinese $14^{\text {th }}$ Five-Year Development Plan consists of 19 parts, and each part is dedicated to a specific topic that will be in focus in the upcoming five years (see Table 1). ${ }^{5}$ All parts have several articles in which the Chinese Government expressed main intentions and measures that will be implemented in order to achieve their goals. In some cases, there are specific data (numbers) that are set as targets for 2026, but in many cases targets are given in a descriptive way. The trend of not giving specific targets in the Plan is in a line with Hu's findings (2013). Hu stated that starting from the $6^{\text {th }}$ Five-Year Plan, the proportion of economic

\footnotetext{
${ }^{3}$ Such as price of the labour, productiveness, mass production, cheap products, etc.

${ }^{4}$ Mainly, but not only them.

${ }^{5}$ Note: In this research, the translation of the Chinese $14^{\text {th }}$ Plan in English, published by the Center for Security and Emerging Techology, a policy research organization within Georgetown University is Walsh School of Foreign Service, USA, was used as a reference. All explanations and terms used in this part of the paper are relying heavily on the text, pages 32 to 38 .
} 
indicators have been dropping, and that was especially evident in the $12^{\text {th }}$ Plan, where the usual ratio of economic versus non-economic indicators of $60 \%$ to $40 \%$, dropped to $12.5 \%$ to $87.5 \%$ (Hu 2013, 631). "Moreover, most of the economic indicators are no longer mandatory plan targets but rather prognostic indicators." (ibidem)

\section{Table 1. Contents of the Chinese $14^{\text {th }}$ Five-Year Development Plan}

Part One: Embarking on the new journey to build China into a modernized socialist country in an all-round way

Part Two: Adhering to innovation-driven development and comprehensively fashioning new development advantages

Part Three: Accelerate the development of a modern industrial system and consolidate and strengthen the foundation of the real economy

Part Four: Forming a strong domestic market and building the new development pattern

Part Five: Accelerate digitalization-based development and construct a digital China

Part Six: Comprehensively deepen reform and build a high-level mechanism for the socialist market economy

Part Seven: Insist on prioritizing the development of agriculture and rural areas and comprehensively promote rural revitalization

Part Eight: Improve the New Urbanization Strategy and Improve the Quality of Urbanization Development

Part Nine: Optimize regional economic layouts and promote coordinated regional development
Part Ten: Develop advanced socialist culture and enhance national cultural soft power

Part Eleven: Promote green development and facilitate the harmonious coexistence of people and nature

Part Twelve: Put high-level opening up to the outside into practice and exploit new situations for win-win cooperation

Part Thirteen: Improve the quality of citizens and promote comprehensive human development

Part Fourteen: Enhance the people's livelihoods and well-being and raise the level of co-construction, co-governance, and sharing

Part Fifteen: Coordinate development and security to construct a more peaceful and secure China

Part Sixteen: Accelerate national defense and armed forces modernization and achieve the mutual unity of a rich country and a strong military

Part Seventeen: Strengthen the construction of socialist democracy and rule of law and improve the Party and state supervision system

Part Eighteen: Adhere to "One Country, Two Systems" and promote the reunification of the motherland

Part Nineteen: Strengthening Plan Implementation Assurance

Source: Center for Security and Emerging Technology, 2021. "Outline of the People's Republic of China $14^{\text {th }}$ Five-Year Plan for National Economic and Social Development and Long-Range Objectives for 2035", English translation of the Chinese official document published on the website of Xinhua on March 12, 2021. https://cset.georgetown.edu/wp-content/uploads/t0284_14th_Five_ Year_Plan_EN.pdf 
As the Table 1 shows, the Plan has a comprehensive outlook of China's future in the field of economy, society, law and politics. Nevertheless, we can identify the main priorities of the Government. In the field of economy, besides implementation of the new development concept, the main strategic focus will be on innovation, modernization of the industrial system, digitalization (of the economy), further implementation of economic reforms, agricultural and urbanrural development, more coordinated regional development and enhanced green development. In other parts of the plan, the focus is on making a better society for Chinese citizens especially in regards to the quality of life, such as better health and social systems, improvement of living conditions in rural areas, less pollution in cities (and country in general) and more sustainable development. The last part of the Plan is political, and provides more information about the main political issues China wants to pay attention to within the next five years. The most important one is the safety of its citizens and providing enough military defence to this purpose, remaining strong in promoting and living in "one country, two systems", and finally, strengthening the construction of socialist democracy and the rule of law, and improving the Party and state supervision system.

The explanation of the new development paradigm - dual circulation, was given in part four, titled Forming a strong domestic market and building the new development pattern. The introduction part dedicated to the dual circulation states: "We will persist in expanding internal demand as a strategic basis, accelerate the cultivation of a complete internal demand system, and organically combine implementation of the internal demand expansion strategy with supply-side structural reform, using innovation-driven, high-quality supply to lead and create new demand (CSET 2021, 32)." The introduction explains that demand and supply within domestic market are the focus of reforms. According to the text, both of them require changes that will start with the better utilization of resources, lead to a better supply, and finally steer higher level of demand. The Government plans to achieve this through innovation and high-quality supply, which will thus generate high-level of demand. Graph 1 presents this process as a circular process, since one change will cause another, and so forth. 
Graph 1. Domestic great circulation reforms

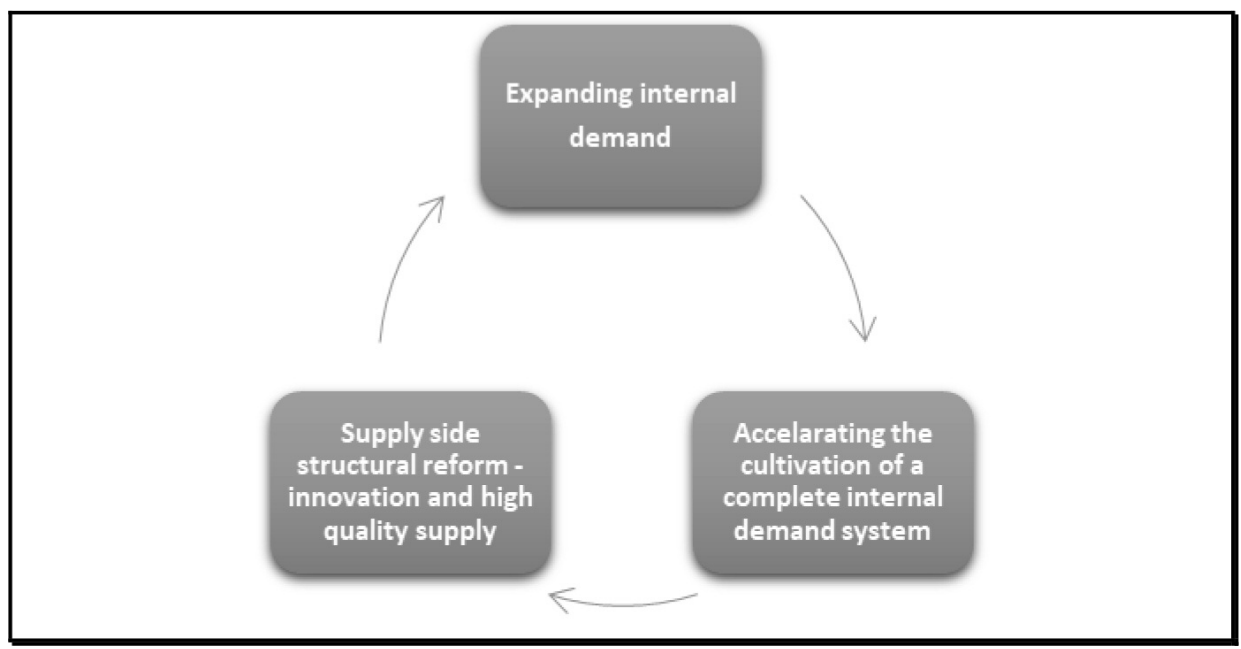

Source: Author

So, the domestic circulation is the part that Government can reform, improve and have control over. The second part of the dual circulation, and that is the part of the international circulation, is the part in which it will be more difficult to control, since China will rely on other international actors to achieve its reforms.

How will China achieve the reforms in the domestic market and change its relation with international market at the same time? The Plan contains three articles that explain the logic of this development concept, and also provide information about the future reforms.

Graph 2. Dual circulation development paradigm

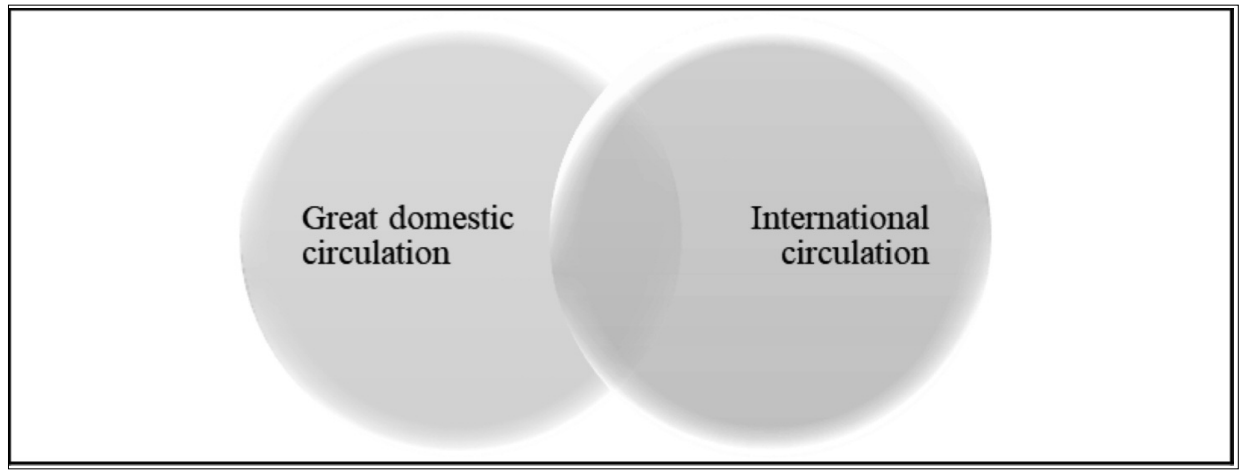

Source: Author 
Article 1 is titled "Facilitate domestic great circulation", and it provides information on the ways to transform the supply and economic means that will provide prompt changes. In total, four main guidelines were given for these reforms:

1. Increase the adaptability of the supply system - the supply will be transformed in a way so that it will be better adjusted to the demand within the domestic market, which will be more quality driven, whether it being the demand for consumer goods or services. Agriculture, manufacturing, service industry and energy sources are emphasized as important in those regards. Also, it is evident that China wants to create strong Chinese brands that will be competitive both on domestic and international market, and one of the ways to achieve this will be to implement international quality standards in a better way than thus far.

2. Promote the smooth flow of resources and factors - the Chinese Government is aware that there are distortions within its market that can be changed so the market is utilized in a better way. The Plan identifies the following "blockages": flow of factors of production, capital supply to the real economy, real estate market, quality of employment, salaries, and disparity between urban and rural development.

3. Strengthen the supporting role of the circulation system - here the main aim is to provide additional help to domestic market by enabling the system to function more efficiently. In that sense, the Government will apply measures that will unify the domestic market by eliminating local protectionism, monopolies or market segmentation. Besides this, there will be changes in supply and logistic chains.

4. Improve policy systems that promote domestic great circulation - this is the final part of the article dedicated to the supply aspect of the reforms. It encompasses measures aimed to improve the tax system, R\&D investments and income distribution. The Government will maintain adequate liquidity, take care of the growth rate of the money supply and scale of social financing.

Article 2 is titled "Promoting domestic-international dual circulation" and it gives an overlook on the way China wants to change its interaction with the international market, and that is by taking care of trade and investments.

1. Firstly, China will promote measures aimed at imports and exports, so that it can have a more coordinated development. The main targets are laws and regulations that will improve some parts of Chinese export and import. In regards to import, the Government will reduce import tariffs, increase import of highquality products, technology, equipment and energy resources. Export will be altered so that quality and the structure of export would lead to the increase of value-added exports. The aim is also to stabilize the markets in which China is already established and improve the exports to the neighbouring countries. 
2. Raise the level of international two-way investment - China will not stop with overseas investments, neither will it stop the inward FDI in China. On the contrary. The Plan highlights several sectors in which China wants to attract foreign investors such as telecommunications, internet, education and healthcare. Besides this, the Chinese Government is aiming to invest in the mid to high-end manufacturing, high technology and modern services. It is stated that investments will be welcomed in the central and western China, which is in line with China's long-term policy for more equal development. Regarding Chinese overseas investments, they will be more risk aware and risk proactive, meaning that Chinese companies will be instructed to improve risk prevention and the level of profitability, while concurrently working on creating recognizable Chinese brands.

Article 3 is titled "Accelerate the cultivation of a complete domestic demand system" and it consists of two parts:

1. Comprehensively promote consumption - this is a very important part of the Plan because it will enable the whole circulation process to function according to the new paradigm. The emphasis is on consumer consumption, but there will be changes in the public consumption as well. Modifications are expected in products and services that have higher quality and that will provide better quality of life for Chinese citizens, such as education, medicine, elder care and childcare, tourism and sports. Furthermore, the Government will support the development of new types of consumption - custom, experiential, intelligent and fashionable consumption. The aim is to expand the middle-income group so that their increase in demand can push the supply aspect further.

2. Broaden the space for investment - China has identified major areas in which it wants to invest in the upcoming cycle: major strategic projects in infrastructure, agricultural and rural areas, public security, ecology and health.

\section{CHALLENGES IN THE IMPLEMENTATION OF THE DUAL CIRCULATION}

"Dual Circulation" is a new development paradigm that will enable China to progress from a middle-income to a high-income country. As such, it is a very ambitious concept and it does put a lot of pressure on all involved parties to achieve planned goals. On that road to change, there will be many challenges that China will need to overcome. In papers published thus far, there is more or less of a consensus on the things that will be difficult to achieve. Nevertheless, we should also be aware that the third year of the COVID-19 pandemic is approaching, and

\footnotetext{
${ }^{6}$ Sichuan-Tibet railway, New Western Land-Sea Corridor, the national water network, hydropower on the river Yarlung-Tsangpo, interplanetary exploration, BeiDou commercialization (CSET 2021, p. 38).
} 
we still cannot see the end of it. Because of that, it is necessary to bear in mind that there are so many uncertainties that will occur during the next five years which will impact the final results of the $14^{\text {th }}$ Development Plan.

Compared to the previous plans, the new Plan has a key difference regarding circulation in the domestic market and that is a steady and increased level of domestic demand. The concept of improving domestic demand within China is a logical step in China's development because there is room for it. According to The World Bank data, final consumption expenditure in \% of GDP in 2019 was $56.02 \%$ in China, $72.8 \%$ in Germany, $83.12 \%$ in the UK, $81.8 \%$ in the USA, and $75.3 \%$ in Japan (TWB a). If we look more carefully and check households and NPISHs final consumption expenditure in \% of GDP in 2019, we will see that the data for China was 39.25\%, Germany 53.39\%, United Kingdom 64.04\%, United States $67.86 \%$, and Japan $55.24 \%$ (TWB b). Hence, while all these countries differ, they are current economic leaders, and by comparing China with them, we can see how much private (household) consumption can increase in China. Previous development phases in China had a different notion and development relied on exports and investments ${ }^{7}$. Nowadays, those economic opportunities are not as powerful as they were before. China is correctly returning to the unfulfilled opportunities in the domestic market.

Even though China is the number two economy in the world, it still has a lot of development potential on the domestic market that has not been realized so far. The progress in China has not been equal in all regions, and there is a vast potential for them to improve their economic progress and expand domestic demand. However, that first step will not be easy to achieve because it will take time to develop them and improve the economic situation of their citizens. Those people will then spend their money instead of saving it.

As Liu pointed out: "China has a population of 400 million in the middle-income group, and strives to double it to 800 million in about 10 years, letting them truly become the majority of the society. At present, there are still 600 million people in China with monthly income less than RMB1.000, which mainly concentrated in the rural areas. Therefore, it is a must to expand the channels of employment and profitgaining for farmers. Of the RMB 41.16 trillion in the total retail sales of consumer goods in China in 2019, rural consumption only accounts for 1/7..." (Liu 2020, 2)

According to these data, the potential of the domestic market is vast. However, the reality is that the income in rural areas is still low. Aside from rural areas, the western and some of the northeast provinces are lagging behind the eastern development, and this did not change much since Jiang Zemin's reforms. Even though all of Deng Xiaoping's successors tried their best to have a more balanced

\footnotetext{
${ }^{7}$ Inward FDI in Special Economic Zones and outward FDI due to the Going Global Policy.
} 
regional development, the east part of the country is still the leader within the Chinese economy.

Map number 1 shows the distribution of rural poverty in China, according to the official Chinese Statistics Bureau (UNICEF). This distribution is in a reverse relation with the regional development - those provinces that are highly developed have lower rural poverty rates. Once again, it showcases that western provinces such as Guizhou, Xinjiang, Gansu, Tibet and Yunnan have much higher rural poverty rates than eastern and northern provinces.

Additionally, it should be noted that the pandemic in China affected lowincome families the most. That was expected, as something similar happened in the rest of the world. Many breadwinners have families living in rural areas while they are temporarily working in big cities. Many of them lost their jobs due to the pandemic and could not find another job. Their position and future are very complex and uncertain. According to Grieger: " $63.35 \%$ of migrant workers surveyed in 2020 stating that they had no job prospects if they returned to their rural home towns, against 35.3\% during the 2008 financial crisis (Grieger 2021, 4)." Moving forward, it will be important to secure continuing development of rural and agricultural areas so that the labour force can stay in their hometowns and provinces and provide income for their families.

Map 1. Rural poverty rate in \%, in China in 2017

(Chinese National Bureau of Statistics)

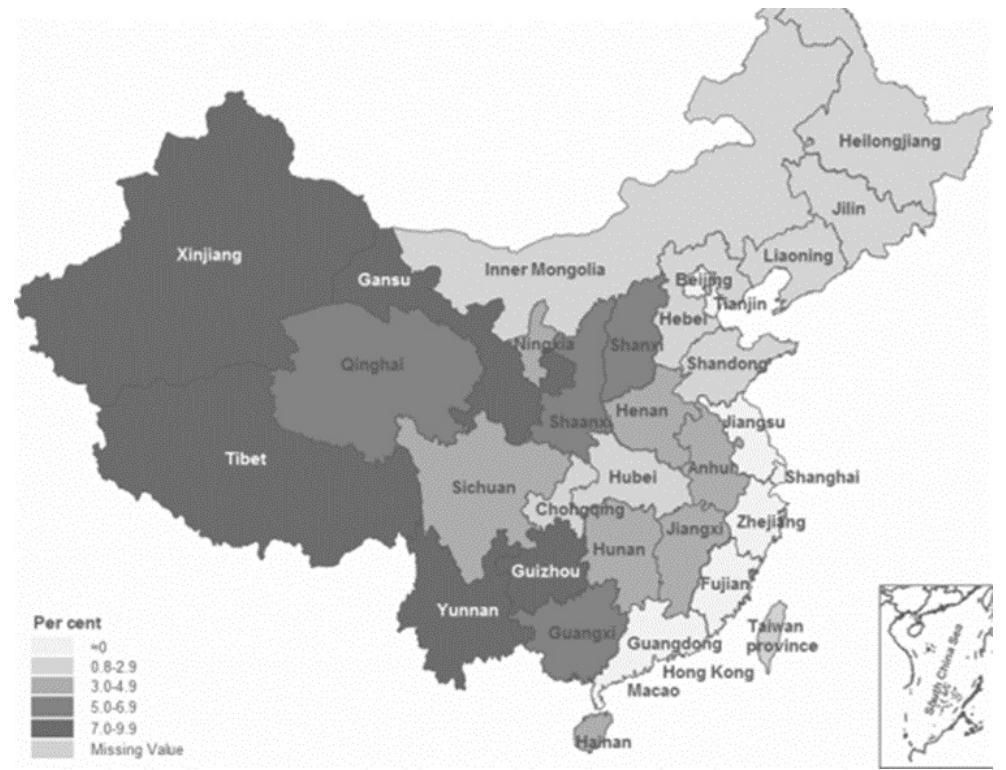

Source: UNICEF, Rural poverty rate, by province, 2017, https://www.unicef.cn/en/figure-211rural-poverty-rate-province-2017 
It will be important, as well, to change the social registration system that provides social benefits to Chinese citizens. Hukou is the registered status of the individual Chinese citizen in the official state system. So far, the system has recognized urban and rural residents, and each group had its rights and responsibilities. Before the reforms in 2014, urban citizens had better status than rural regarding pensions, educations and health care. Since the pressure of rural workers in big cities was constant, the Government decided how many migrant rural workers can come to big cities. In addition to this restriction, those workers had limited social benefits that did not provide enough security. Since one of the strategic goals in the new Plan is to provide more social security to the rural population, the local provinces with mainly rural citizens will have a leading role in addressing this issue. Besides them, provincial leaders in big cities also need to address the reforms, so that they can provide better working and health conditions for migrant workers.

Since one of the main drivers of the economic development in the new Plan is the domestic demand, according to the documents, the demand needs to be accompanied by a supply that is more innovation-driven. If China wants to have a more innovative production of goods and services, this means that it will need to have a more highly skilled labour force. So far, due to the structure of the manufacture industry and services, there was no high demand for high-skilled workers in China. Since there is a sincere orientation towards the changes within the IT industry and industry in general, China will have a higher demand for them, but currently, China does not have enough of them.

One of the things that will be difficult to change is the cultural habits of Chinese people, and one in particular - savings. For many decades, Chinese people were immensely into saving. It was the same with the Government and enterprises. China is in the top 10 countries in the world in regards to gross domestic savings rate (percentage of GDP), and besides households, it includes corporate and government savings. In 2019, the gross domestic savings rate in China was 44\%, while the world average was $25.31 \%$ (TWB c). Asian nations are usually more oriented towards savings than, for example, European nations. Such economic behaviour, deeply rooted in the nation's culture, is complicated to change. Even if the Government and corporations increase spending, there still would be a need to have an increase in household spending.

Chinese demographic situation is currently not bright. Due to the "One Child Policy", the number of children and the labour force will start to significantly decrease after 2035. The reforms in this field started in 2016 with the change of law, which allowed two children per family. In May 2021, it was announced that China would allow three children per family to achieve better birth rates. Even though first changes started in 2016, it will take a while for policies to have substantial effects on the number of new-borns. The Chinese National Bureau of 
Statistics (NBS) published reports in 2021 in which it was evident that despite the new laws, the numbers are not increasing, on the contrary, they are decreasing. In 2020, there were 12 million births, while in 2019, they were 14.56 million (Global Times 2021). According to the NBS, year 2020 is the fourth consecutive year in which the number of new-borns is declining. At the same time, the fertility rate is decreasing. Zhao and Zhang (2021) wrote that in 2020, the fertility rate was 1.3, and in 2017 it was 1.6. They argue that the third child policy can bring the increase of the number of new-borns in the short term, which would not be sufficient to improve the number of the labour force. They suggested that this policy should be supported by: "Improving population health (especially at older ages), postponing the retirement age and raising the productivity of workers are more effective and complementary long-term strategies that should be considered (ibidem)."

On the supply side, two main challenges can be identified: reforms of stateowned enterprises (SOE) and push for the innovation development. SOEs are truly the trademark of Chinese reforms that started in 1979, and without them, the development achieved so far could not be accomplished. However, there is always room for improvement. Due to their favourable position, some of them were not utilizing their resources in the best way ${ }^{8}$, and they were lacking ability to keep pace with the rapid changes that were happening on the Chinese market. The organizational structure in SOEs is rigid and hierarchical, and does not allow the organizational culture to be flexible, fast or in many cases innovative. Nonetheless, like the rest of the Chinese society, they also need to change.

Private companies in China are the champions of today's China development, since their contribution to the GDP is $60 \%$ (Zitelmann 2019). According to the World Economic Forum: "The combination of numbers 60/70/80/90 are frequently used to describe the private sector's contribution to the Chinese economy: they contribute $60 \%$ of China's GDP, and are responsible for $70 \%$ of innovation, $80 \%$ of urban employment and provide $90 \%$ of new jobs. Private wealth is also responsible for $70 \%$ of investment and $90 \%$ of exports (ibidem)." It is evident that the success of the new paradigm will be deeply connected and related to the private sector since they are the leaders in the field of innovation. China will carefully balance the potential of innovation with the need to protect national security. Recent examples of unsuccessful IPOs on the international financial market of internet companies such as Alibaba (Alipay) and Didi Chuxing, are showing that even though the companies have big success and potential for growth, the data that they have in their hands is too worthy to be in the hands of private investors from foreign markets. That does mean that if these kinds of

${ }^{8}$ Sometimes due to objective reasons, but many times due to inefficiency. 
companies want to gather capital for future investments and innovations, that capital must come from domestic investors. Therefore, between the need to innovate and rely on private companies, and the need to achieve strategic goals within new development paradigm, there will be a narrow space to utilize the opportunities and the ability to allow the development of private companies.

\section{WORLD AND CHINA - EFFECTS OF THE 14TH FYP ON THE WORLD ECONOMY}

China's domestic and international circulation discussed above will have various effects on the functioning of the world economy. Even though the reforms are within the domestic market, China, as one of the global economic leaders, influences global economic trends. For this reason, it should be explained in which ways the international economy will change due to the changes in the Chinese market.

Zhu, in her analysis of Dual Circulation, points out a simple fact: "An economy based on 'domestic circulation', expects domestic demand to grow faster than foreign trade, while an economy 'based on international circulation' expects foreign trade demand to grow faster than domestic demand growth or GDP growth (Zhu 2020 , 4)." Therefore, due to the changes in the domestic demand and production, Chinese reforms will have a substantial impact on its imports and outward FDI.

At the beginning of this article, it is stated that many Western scholars see Dual Circulation as decoupling from the world, whether we analyse trade or investments. In accessing this observation, let us look at some previous facts. Dependency of the Western markets on China's export grows slowly over time, and Western economies wanted that kind of cooperation due to cheap Chinese export products, which enabled their economies to focus on the production of high-quality products, with more added value and with much higher price tag then Chinese. Seeing that this kind of cooperation benefited both parties, and while there were no external economic shocks, no one was complaining about the division of labour, export-import rates or global supply chains. However, the global financial crisis (GFC) in 2008-2009 changed the perspectives of the West. Since the crisis affected Western economies the most, and since China used this time to pursue its Going Global Policy even more and bought many companies, Western countries realized that existing economic relations were not benefiting them. With that, protectionism measures started to increase word wide. In her recent article, Stanojević pointed out that European protectionism measures increased after the GFC and COVID19. She used data analysis to prove that trade barriers, shortening of global supply chains and restrictions for FDIs in Europe are growing in recent years (2020, 419420). It is also interesting that, in terms of trade, the EU has trade restrictions that exceed those of the US (ibidem). China is no exception to these EU policies, 
especially knowing that the Foreign Direct Investment Screening Regulation that the EU adopted in 2019 further pushed down the volume and number of Chinese FDIs in the EU (Zakic 2021, 455-456). At the same time, the US and China are still in a state of a trade war that is not resolved. Having all this in mind, is China really decoupling from the world? The answer is yes and no. As Grieger points out: "However, China is not de-coupling from the world. The signature of the Regional Comprehensive Economic Partnership (RCEP) by China and 14 negotiating partners in the Asia-Pacific on 15 November 2020 is testimony to China's continued global economic integration, committing it to trade rules it has shaped from the outset $(2020,9)$." In other words, China will be more oriented towards economic cooperation with neighbouring countries, as well as with countries that are a part of the Belt and Road initiative. We can find those references even in the $14^{\text {th }}$ Plan. Still, China is aware of the uncertainties in the world, protectionism measures, and public opinion in the Western countries towards China. It will not go into decoupling full force as the US and the EU did, but it will find opportunities elsewhere.

Regionalization is probably the term that will be, as time goes by, used more to describe events that will happen in the world economy. Orientation towards relatively closer countries that share the same objectives and views regarding the world economy and politics will be more pronounced'. The pandemic only sped up the process of regionalization that was slowly starting to develop pre-pandemic. As opposed to the glory days of globalization, where the global community was advocating for free movement of capital, goods and people, nowadays things are changing. Due to the pandemic, countries realized their vulnerability in many ways. Notably, regarding global supply chains, health, food and energy security. This will inevitably lead to more self-reliance, as much as countries can manage in their specific situation. China will do so as well. Energy security in China cannot be much improved, but health and food security can. In addition, due to China's vulnerable position in regards to semiconductors, China will be focused on developing technologies that will enable it to become more advanced so that it could depend less on other countries.

According to the new Plan, China will slowly put down protectionism measures regarding inward FDIs. Those policies will enable foreign companies to invest more in some sectors in China they could not invest so much before (e.g. health sector, tourism, IT). China will still protect certain parts of its industries and services that it recognizes as strategic. Companies that want to invest in the Chinese market should carefully follow new instructions, especially those given by provincial

\footnotetext{
${ }^{9}$ Such as RCEP, ASEAN, EU, NAFTA etc.
} 
governments, because they will have precise information regarding the type of industry or services open for outward FDI.

Global production and supply chains are currently restructuring due to the pandemic, and it will be interesting to see how much time and financial resources are countries willing to spend to gain more independence over China. Decoupling from China will unquestionably lead to an increase in prices in some types of products, and probably in some cases to market shortages.

Western countries will be faced with a decision - how much they want to aggravate their situation with China, and what is the price that they wish to pay, both in an economic and political sense. Looking ahead, it is difficult to see if the US will change its recent course towards China. So far, President Biden did not change the narrative or policies that former president Trump introduced. We can observe the continuing process of decoupling with China. The US will start to cooperate even more with countries in Asia that are its allies, as well as with the EU and Latin America. The trade war with China will probably continue with many more negotiation phases in between. Judging by the results of the trade war so far, the winners were third countries, such as Argentina, Brazil, Mexico, South Korea, Thailand and Vietnam. Those countries benefited the most due to the trade war, and they seized a great opportunity. If the US further continues to pressure China in the economic sense, that will probably lead to further decoupling, but at the same time, some other countries will benefit from that process.

The EU and China have a more complicated situation to discuss and solve. The number of states within the EU that have completely different opinions about cooperation with China is significant. While Hungary is very pro-China, Baltic States are not. The German Government views on the cooperation with China differ from its citizens. While the Government is thinking strategically, and is proChina, German citizens do not share the same sentiment. In 2020, China became EU's number one trading partner, and that trend did not end in 2021. Trade relations are on a record high level, while Comprehensive Agreement on Investments (CAI) is still not officially signed, and investments are not as high as they were. However, most EU countries are not satisfied with their large trade deficit with China and want to change this. In addition, the pandemic showed that the supply chains are too long and that the countries within the EU need to think about shortening the supply chains and becoming more self-reliant. The EU, like China, has some unused opportunities within its market, as well as the countries in process of joining the EU. At the moment, many countries in Europe are probably considering how to change and utilize this situation and gain a market advantage. Balkan countries can also potentially have more business opportunities, because they are close to the EU market, the labour force is highly skilled with salaries well below those in the Union, they have good environment for outward 
FDI, laws are mainly in accordance with the EU's, political environment is relatively stable and national and corporate culture is familiar to the EU's companies.

\section{CONCLUSION}

"Dual Circulation" as a new official development paradigm is a logical and practical step in the next phase of Chinese development. Previous development models and policies that relied on exports and foreign direct investments (both inward and outward) were successful and enabled China to become a modern economy. China altered its development patterns and development policies so that they are in line with the times and circumstances. Each phase was contemplated with great attention, and time proved that they were the right choices.

This development model is considerably different, and it reflects new circumstances both inside and outside China. Previous opportunities are not sufficient anymore in order to allow China to progress from a middle to a highincome country. The so-called middle-income trap is a real problem, and many countries failed in their efforts to transition from middle to high-income countries. China is in a unique position in those regards because it has unused opportunities in the domestic market. Reforming the domestic market, especially domestic demand, will enable China to continue with other reforms. For the first time since the Open Door Policy, China will shift its focus from foreign markets and concentrate its efforts on the domestic market. Also, it will need to continue with the planned activities and put emphasis on innovative development. A significant amount of resources (material, financial and human) should be placed in advanced science and technology (S\&T) and information technology (IT) in order for the model to function.

Not much will change regarding international circulation. China will still invest abroad, but in different projects than before. More outward investments will go into the IT sector, sustainable development, health services and research. China's neighbouring countries and those being a part of the Belt and Road initiative will become the preferred destination. Regarding inward FDIs, there are sectors in which China will allow more investments, and it will adjust legal regulations allowing easier access of foreign FDI to its market. Exports will be an important part of the economy, but not as before. China is aware that its products are not so cheap anymore and that protectionism measures are increasing, so it will change its policies according to these trends. Imports will be slightly modified as well. The structure will be altered so to better suit the needs of the Chinese market.

The main challenges in the implementation of the new development concept will be expanding domestic demand, having more equal regional development, increasing the domestic income, implementing changes within hukou, increasing 
high skilled labour force, changing the culture of savings, reforming the stateowned enterprises, and having innovative development. Each challenge is equally important in the grand scale of things, so careful planning, realization and adjustment will help achieve necessary reforms and successful implementation of "Dual Circulation".

Of course, many opportunities within the Chinese market could be the reason why a new development model is successful. There is vast domestic potential, such as the size of the market and the population that can increase their income, which can be utilized in a better way. China has gained experience and is working a lot on IT and S\&T development. In the recent years, China holds the first place in the world when it comes to the number of patents. In terms of investing in green development, China is also in the first place in the world. The resilience of the Chinese economy was evident during the pandemic in 2020. China quickly responded to and embraced new circumstances, and ended that year as one of the rare countries with positive economic results. There is no doubt that the Chinese experts and Government took into every possible scenario account in formulating the Plan and the development paradigm. This development phase was the logical and pragmatic step in the evolution of China and the right way to achieve centennial goals, even though it will not be an easy task.

The main expected changes within the world economy will be regionalization, self-reliance and changes within global production and supply chains. Those changes will not solely happen because of China's new paradigm. On the contrary, they were happening already, but on a smaller scale. Nowadays, especially due to the pandemic, and of course due to China's new development model, things will change. For some countries, there will be plenty of new opportunities, and for some new difficulties to overcome. However, changes are an integral and a necessary part of the economy, and the main task is to detect and embrace them. Those that do not succeed in this will not be a part of the success story.

\section{REFERENCES}

Aglietta Michel, Guo Bai \& Camille Macaire. May 2020. “The 14th Five-year Plan in the New Era of China's Reform: Asian Integration, Belt and Road Initiative and Safeguarding Multilateralism”, Policy Brief No 2020-36, CEPII, pp. 1-13, http://www.cepii.fr/PDF_PUB/pb/2021/pb2021-36.pdf

Blanchette Jude \& Polk Andrew. 2020. "Dual Circulation and China's New Hedged Integration Strategy", Center for strategic and international studies, August 24, https://www.csis.org/analysis/dual-circulation-and-chinas-new-hedgedintegration-strategy 
Bramall Chris. 2008. Chinese Economic Development, London and New York: Routledge, Taylor and Francis Group

[CSET] Center for security and emerging techologies, 2021. "Outline of the People's Republic of China 14th Five-Year Plan for National Economic and Social Development and Long-Range Objectives for 2035", English translation of the Chinese offical document published on the website of Xinhua from March 12, 2021. https://cset.georgetown.edu/wp-content/uploads/t0284 _14th_Five_Year_Plan_EN.pdf

Global Times. 2021. "China's fertility rate may become 'world's lowest' without strong intervention policy, India may overtake China by 2023: demographers", Global Times, May 11, https://www.globaltimes.cn/page/202105/12231 41.shtml

Grieger Gisela. 2020. "China's economic recovery and dual circulation model", European Parliament, European Parliamentary Research Service, December, PE 659.407, pp. 1-12, https://www.europarl.europa.eu/RegData/etudes/ BRIE/2020/659407/EPRS_BRI(2020)659407_EN.pdf

Hong Yinxing. 2018. "The major innovations of Chinese economic development theories in the new era", China Political Economy, Vol. 1 No. 1, Emerald Publishing Limited, pp. 13-29, DOI: 10.1108/CPE-09-2018-006

Hu Angang. 2013. “The Distinctive Transition of China's Five-Year Plans”, Modern China, 39(6), SAGE Publications, pp. 629-639, DOI: 10.1177/0097700 413499129

Kwan Hung Chi. 2021. "Dual Circulation” as China's New Development Strategy - Toward a Virtuous Cycle between Domestic and International Circulations, Research Institute of Economy, Trade and Industry, January 13, https://www.rieti.go.jp/en/china/20101301.html

Lin Justin Yifu \& Xiaobing Wang. 2021. "Dual Circulation: A New Structural Economics View of Development", Journal of Chinese Economic and Business Studies, Routledge, Taylor \& Francis Group, pp. 1-21, DOI: 10.1080/14765284.2021.1929793

Liu Hong. 2020. "New Development Pattern of "Dual Circulation" in Mainland China and Hong Kong's Role“, Economic Review, August, Hong Kong Financial Research Institute, https://www.bochk.com/dam/investment/bocecon/ SY2020023(en).pdf

Lu Ding. 2016. “China’s 'Two Centenary Goals': Progress and Challenge”, East Asian Policy, Vol. 08, No. 2, pp. 79-93. DOI: 10.1142/S1793930516000222, https://www.researchgate.net/publication/304669725_China's_Two_Centena ry_Goals_Progress_and_Challenge 
Pettis Michael. 2020. “The problems with China's 'Dual Circulation' economic model”, Financial Times, August 25, https://www.ft.com/content/a9572b586e01-42c1-9771-2a36063a0036

[TWB] The World Bank, GDP per capita (current US\$) - China, https://data.worldbank.org/indicator/NY.GDP.PCAP.CD?locations $=\mathrm{CN}$

[TWBa] The World Bank a, Final consumption expenditure (\% of GDP) - China, https://data.worldbank.org/indicator/NE.CON.TOTL.ZS?locations $=\mathrm{CN}$

[TWBb] The World Bank b, Households and NPISHs final consumption expenditure (\% of GDP) - China, Germany, United Kingdom, United States, Japan, https://data.worldbank.org/indicator/NE.CON.PRVT.ZS?locations $=\mathrm{CN}-\mathrm{DE}-\mathrm{GB}-\mathrm{US}-\mathrm{JP}$

[TWBc] The World Bank c, Gross domestic savings (\% of GDP), https://data. worldbank.org/indicator/NY.GDS.TOTL.ZS?most_recent_value_desc=false \&year_high_desc $=$ true

Saad Ahmed Javed, Yu Bo, Liangyan Tao \& Wenjie Dong. 2021. "The 'Dual Circulation' development model of China: Background and insights", Rajagiri Management Journal, Emerald Publishing Limited, pp. 1-19, DOI 10.1108/ RAMJ-03-2021-0016

Sheng Andrew. 2021. "Dual circulation is a strategic process, not a theory", East Asia Forum, January 20, https://www.eastasiaforum.org/2021/01/20/dualcirculation-is-a-strategic-process-not-a-theory/

Shusong Ba \& Haifeng Bai. 2020. "Covid-19 pandemic as an accelerator of economic transition and financial innovation in China", Journal of Chinese Economic and Business Studies, 18:4, Routledge, Taylor and Francis Group, pp. 341-348, DOI: 10.1080/14765284.2020.1855394

Stanojević Nataša. 2021.“The rise of European protectionism”, in: Zakić Katarina and Birgül Demirtaş, "Europe in changes: The old continent at a new crossroads", Institute of International Politics and Economics, Belgrade, Faculty of Security Studies, University of Belgrade, pp. 407-423, DOI: 10.18485/iipe_euchanges.2021.ch20

UNICEF, Rural poverty rate, by province, 2017, https://www.unicef.cn/en/figure211-rural-poverty-rate-province-2017

Xinhua. 2017. "CPC Q\&A: What are China's two centennial goals and why do they matter?" Xinhuanet, October 17, http://www.xinhuanet.com/english/ 2017-10/17/c_136686770.htm

Zakić Katarina \& Meixing Sun. 2021. "The Results of Economic Co-Operation between the EU and China amid the COVID-19 Pandemic", in: ed. Katarina Zakić and Birgül Demirtaş, "Europe in Changes: The Old Continent at a New Crossroads", p. 445-463, DOI: 10.18485/iipe_euchanges.2021.ch22 
Zhao Zhongwei \& Guangyu Zhang. 2021. "The reality of China's fertility decline", East Asia Forum, 8 July, https://www.eastasiaforum.org/2021/07/08/thereality-of-chinas-fertility-decline/

Zhu Viviana. 2020. "China's Dual Circulation Economy", China Trends, Institute Montaigne, https://www.institutmontaigne.org/ressources/pdfs/publications /china-trends-7-EN.pdf

Zitelmann Riner. 2019. "State Capitalism? No, The Private Sector was and is the Main Driver of China's Economic Growth", Forbes, 30 September, https://www.forbes.com/sites/rainerzitelmann/2019/09/30/state-capitalismno-the-private-sector-was-and-is-the-main-driver-of-chinas-economicgrowth/?sh $=5 \mathrm{~d} 80 \mathrm{dc} 9 \mathrm{c} 27 \mathrm{cb}$

\section{NOVA RAZVOJNA PARADIGMA U KINESKOM 14. PETOGODIŠNJEM PLANU - KINESKA VIZIJA MODERNE KINE}

Apstrakt: Dualna cirkulacija je nova kineska razvojna paradigma koja je prezentovana u poslednjem 14. petogodišnjem planu. Autor ovog članka objašnjava razlog njenog nastanka, način na koji će se sprovoditi, kao i glavne izazove koji su na putu postizanja ciljeva definisanih u planu. Dualna cirkulacija je logičan korak u evoluciji kineske ekonomije, a planirani rezultati su ambiciozni. Glavni očekivani izazovi u njenoj implementaciji su uvećanje domaće tražnje, ravnomerniji regionalni razvoj, povećanje domaćeg dohotka, promene unutar bukou sistema, povećanje broja visoko kvalifikovane radne snage, promena kulture štednje, reforma državnih preduzeća i inovativni razvoj. Glavne očekivane promene u svetskoj ekonomiji su regionalizacija, samodovoljnost, kao i promene unutar globalnih lanaca proizvodnje i ponude.

Ključne reč́: nova razvojna paradigma, Kina, 14. petogodišnji plan, dualna cirkulacija, izazovi, promene

Received: 01.09.2021

Accepted: 01.10.2021 